\title{
Evaluation of Sorbent Injection for Mercury Control
}

\author{
Quarterly Technical Report \\ Reporting Period: July 1, 2004-September 30, 2004
}

Principal Author:

Sharon Sjostrom

\begin{abstract}
ADA-ES, Inc.
8100 SouthPark Way, Unit B

Littleton, Colorado 80120
\end{abstract}

Submitted: October 29, 2004

DOE Cooperative Agreement No.: DE-FC26-03NT41986

Report No. 41986R04 


\section{DISCLAIMER}

This technical report was prepared with the support of the U.S. Department of Energy, under Award No. DE-FC26-03NT41986. However, any opinions, findings, conclusions, or recommendations expressed herein are those of the author(s) and do not necessarily reflect the views of the DOE.

This report was prepared as an account of work sponsored by an agency of the United States Government. Neither the United States Government nor any agency thereof, nor any of their employees, makes any warranty, express or implied, or assumes any legal liability or responsibility for the accuracy, completeness, or usefulness of any information, apparatus, product, or process disclosed, or represents that its use would not infringe privately owned rights. Reference herein to any specific commercial product, process, or service by trade name, trademark, manufacturer, or otherwise does not necessarily constitute or imply its endorsement, recommendation, or favoring by the United States Government or any agency thereof. The views and opinions of authors expressed herein do not necessarily state or reflect those of the United States Government or any agency thereof. 


\begin{abstract}
The power industry in the U.S. is faced with meeting new regulations to reduce the emissions of mercury compounds from coal-fired plants. These regulations are directed at the existing fleet of nearly 1,100 boilers. These plants are relatively old with an average age of over 40 years. Although most of these units are capable of operating for many additional years, there is a desire to minimize large capital expenditures because of the reduced (and unknown) remaining life of the plant to amortize the project. Injecting a sorbent such as powdered activated carbon into the flue gas represents one of the simplest and most mature approaches to controlling mercury emissions from coal-fired boilers.

The overall objective of the test program described in this quarterly report is to evaluate the capabilities of activated carbon injection at four plants with configurations that together represent $78 \%$ of the existing coal-fired generation plants. This technology was successfully evaluated in NETL's Phase I tests at scales up to $150 \mathrm{MW}$, on plants burning subbituminous and bituminous coals and with ESPs and fabric filters. The tests also identified issues that still need to be addressed, such as evaluating performance on other configurations, optimizing sorbent usage (costs), and gathering longer-term operating data to address concerns about the impact of activated carbon on plant equipment and operations. The four sites identified for testing are Sunflower Electric's Holcomb Station, AmerenUE's Meramec Station, AEP's Conesville Station, and a site burning a blend of bituminous and subbituminous coals with a cold-side ESP.

This is the fourth quarterly report for this project. Long-term testing was completed at Holcomb during this reporting period and baseline testing at Meramec was begun. Preliminary results from long-term testing at Holcomb are included in this report. Planning information for the other three sites is also included. In general, quarterly reports will be used to provide project overviews, project status, and technology transfer information. Topical reports will be prepared to present detailed technical information.
\end{abstract}




\section{TABLE OF CONTENTS}

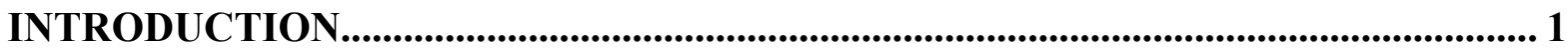

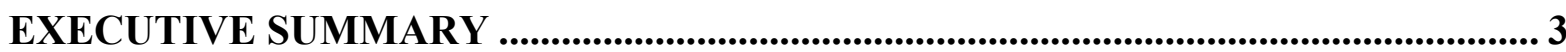

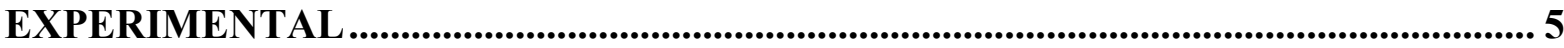

Task 1. Design and Fabrication of Sorbent Injection System........................................ 5

Task 2. Site-Specific Activities Including Field-Testing .................................................... 5

Subtask 2.1. Host Site Planning and Coordination.................................................... 8

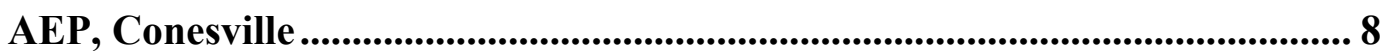

Subtask 2.2. Design, Fabricate, and Install Equipment ...........................................9

Subtask 2.3. Field-Testing ............................................................................................. 10

2.3.1 Sorbent Selection.......................................................................................... 10

2.3.2 Sample and Data Coordination ................................................................... 10

2.3.3 Baseline Testing................................................................................................ 12

2.3.4 Parametric Testing................................................................................. 12

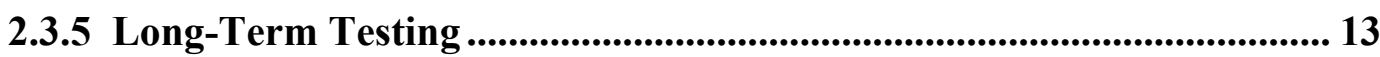

Subtask 2.4. Data Analysis ........................................................................................... 13

Subtask 2.5. Coal and Byproduct Evaluation ............................................................ 13

Subtask 2.6. Economic Analysis ................................................................................. 14

Subtask 2.7. Site Report ................................................................................................... 14

Task 3. Technology Transfer ............................................................................................... 14

Task 4. Program Management and Reporting................................................................... 14

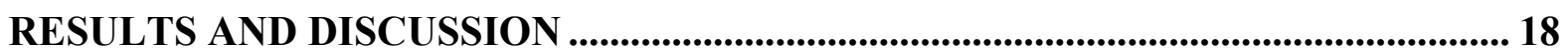

Task 1. Design and Fabrication of Sorbent Injection System....................................... 18

Task 2. Site-Specific Activities Including Field-Testing................................................. 18

Subtask 2.3. Field-Testing, Holcomb Station ............................................................. 18

2.3.1 Sorbent Selection................................................................................................ 18

2.3.2 Sample and Data Coordination ..................................................................... 18

2.3.3 Baseline Testing.......................................................................................... 18

2.3.4 Parametric Testing................................................................................. 18

2.3.5 Long-Term Testing ................................................................................. 18

Subtask 2.4. Data Analysis ................................................................................... 19

Subtask 2.5. Coal and Byproduct Evaluation ............................................................. 19

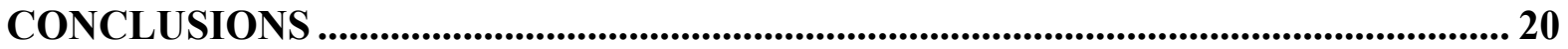




\section{LIST OF TABLES}

Table 1. Host Site Key Descriptive Information. .......................................................2

Table 2. Host Sites Participating in the Sorbent Injection Demonstration

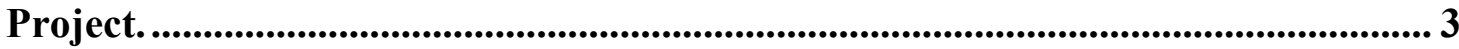

Table 3. Task 2 Subtasks (to be repeated at each test site). .............................................5 5

Table 4. Example of Sample Collection Schedule.................................................................. 11

Table 5. Project Schedule and Milestones. ......................................................................... 15

Table 6. Field-Testing Schedule.............................................................................................. 17

\section{LIST OF FIGURES}

Figure 1. Sketch of Holcomb Unit 1 Spray Dryer Absorber and Fabric Filter

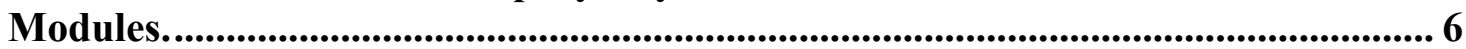

Figure 2. Sketch of East Half of Meramec Unit 2 Testing Layout. ......................................... 7

Figure 3. Photo of East ESP Inlet Duct, Meramec Unit 2.................................................. 8

Figure 4. Photo of Injection Silo Installation at Meramec.................................................9

Figure 5. Photo of Injection Silo Control User Interface at Meramec.................................. 10

Figure 6. ESP Hopper Layout at Meramec.......................................................................... 12

Figure 7. Mercury Removal During 30-Day Continuous Injection of FGD-E3.................. 19 


\section{INTRODUCTION}

The overall objective of this test program is to evaluate the capabilities of activated carbon injection at four plants with configurations that together represent $78 \%$ of the existing coalfired generation plants. This technology was successfully evaluated in NETL's Phase I tests at scales up to $150 \mathrm{MW}$, on plants burning subbituminous and bituminous coals and with ESPs and fabric filters. The tests also identified issues that still need to be addressed, such as evaluating performance on other configurations, optimizing sorbent usage (costs), and gathering longer-term operating data to address concerns about the impact of activated carbon on plant equipment and operations. A summary of the key descriptive parameters for the host sites can be found in Table 1. Selection of Site 4 will be finalized during a team meeting on October 27, 2004. Operating parameters for Site 4 are included in Table 1.

The technical approach that will be followed during this program will allow the team to: 1) effectively evaluate activated carbon and other viable sorbents on a variety of coals and plant configurations, and 2) perform long-term testing at the optimum condition for at least one month. These technical objectives will be accomplished by following a series of technical tasks:

Task 1. Design and Fabrication of Sorbent Injection System

Task 2. Site-Specific Activities including Field-Testing (Four Sites)

Task 3. Technology Transfer

Task 4. Program Management and Reporting

Tasks 1, 3, and 4 are intended to support the overall direction, implementation, technology transfer, and management of the program. Task 2 will be repeated for each test site with subtasks designed to address the specific configurations, needs, and challenges of that site. Task 2 is the heart of the program and contains subtasks to address each important component of the testing. A summary of the Field-Testing subtasks (Task 2) is presented in Table 2. 
Table 1. Host Site Key Descriptive Information.

\begin{tabular}{|l|l|l|l|l|}
\hline & Holcomb & Meramec & Conesville & Site 4 \\
\hline Test Period & $3 / 04-8 / 04$ & $8 / 04-11 / 04$ & $3 / 05-7 / 05$ & $8 / 05-11 / 05$ \\
\hline Unit & 1 & 1 or 2 & 5 or 6 & $?$ \\
\hline Size $(\mathrm{MW})$ & 360 & 140 & 400 & $?$ \\
\hline Coal & PRB & PRB & Bituminous & PRB/Bit blend \\
\hline Particulate Control & $\begin{array}{l}\text { Joy Western } \\
\text { Fabric Filter }\end{array}$ & $\begin{array}{l}\text { American Air } \\
\text { Filter ESP }\end{array}$ & $\begin{array}{l}\text { Research- } \\
\text { Cottrell ESP }\end{array}$ & ESP \\
\hline \multicolumn{1}{|c|}{ SCA $\left(\mathrm{ft}^{2} / \mathrm{kacfm}\right)$} & NA & 320 & 301 & Small \\
\hline Sulfur Control & $\begin{array}{l}\text { Spray Dryer } \\
\text { Niro Joy } \\
\text { Western }\end{array}$ & $\begin{array}{l}\text { Compliance } \\
\text { Coal }\end{array}$ & $\begin{array}{l}\text { Wet Lime } \\
\text { FGD }\end{array}$ & $\begin{array}{l}\text { Compliance } \\
\text { Coal }\end{array}$ \\
\hline Ash Reuse & Disposal & $\begin{array}{l}\text { Sold for } \\
\text { concrete }\end{array}$ & $\begin{array}{l}\text { FGD Sludge } \\
\text { Stabilization }\end{array}$ & Sold \\
\hline Test Portion $(\mathrm{MWe})$ & 180 and 360 & 70 & 400 & $?$ \\
\hline Typical Inlet Mercury $\left(\mu \mathrm{g} / \mathrm{dNm}^{3}\right)$ & $10-11$ & $10-12$ & 15.8 & $?$ \\
\hline Typical Mercury Removal & $0-13 \%$ & $15-30 \%$ & $56 \%$ & $<30 \%$ \\
\hline
\end{tabular}

A detailed topical report will be prepared at the end of the one-year test period. Quarterly reports will be used to provide project overviews, status, and technology transfer information. 


\section{EXECUTIVE SUMMARY}

This four-site project is part of an overall program funded by the Department of Energy's National Energy Technology Laboratory (NETL) and industry partners to obtain the necessary information to assess the feasibility and costs of controlling mercury from coalfired utility plants. Host sites that will be tested as part of this program are shown in Tables 1 and 2. These host sites reflect a combination of coals and existing air pollution control configurations representing $78 \%$ of existing coal-fired generating plants and potentially a significant portion of new plants. These four host sites will allow documentation of sorbent performance on the following configurations:

Table 2. Host Sites Participating in the Sorbent Injection Demonstration Project.

\begin{tabular}{|l|l|l|l|l|}
\hline & Coal / Options & APC & $\begin{array}{l}\text { Capacity MW / } \\
\text { Test Portion }\end{array}$ & $\begin{array}{l}\text { Current Hg } \\
\text { Removal (\%)* }\end{array}$ \\
\hline $\begin{array}{l}\text { Sunflower Electric's } \\
\text { Holcomb Station }\end{array}$ & PRB \& Blend & SDA - Fabric Filter & $\begin{array}{l}360 / 180 \text { and } \\
360 / 360\end{array}$ & $0-13$ \\
\hline $\begin{array}{l}\text { AmerenUE's } \\
\text { Meramec Station }\end{array}$ & PRB & ESP & $140 / 70$ & $15-30$ \\
\hline $\begin{array}{l}\text { American Electric } \\
\text { Power's (AEP) } \\
\text { Conesville Station }\end{array}$ & Bituminous Blend & ESP + Wet FGD & $400 / 400$ & 56 \\
\hline Site 4 & PRB/Bit Blend & ESP & $?$ & $<30 \%$ \\
\hline
\end{tabular}

* Based upon recent Ontario Hydro measurements, except Meramec.

During the fourth reporting quarter, July through September 2004, progress on the project was made in the following areas:

\section{Sunflower Electric Power Corporation, Holcomb Station}

- Conducted long-term testing July 6-August 7, 2004

- From Day 6 through 30, the injection concentration was set for nominally 1.2 lb/MMacf. The average removal for the 30-day test was 93\% for Days 6 through 30. The average outlet concentration for Days 6 through 30 was $1.13 \mu \mathrm{g} / \mathrm{Nm}^{3}$ $(0.83 \mathrm{lb} / \mathrm{TBTU}$, standard deviation $=0.30 \mathrm{lb} / \mathrm{TBTU})$.

- Decommissioned equipment and moved to Meramec

\section{AmerenUE, Meramec}

- Baseline testing August 23-27, 2004

- Parametric testing August 30-September 27, 2004

- DARCO FGD August 30-September 3, 2004

- Halogen-treated carbon (FGD-E3) September 14-17, 2004

- Coal additives with and without DARCO FGD, September 18-October 1, 2004 


\section{AEP, Conesville}

- Site visit to review equipment installation locations

- Began assembling data for flow modeling of ESP inlet

- Continued working on host site agreement

- Began preparing plant procurement tasks

Site 4

- Contacted several utilities with appropriate configurations to discuss hosting fall 2005 tests 


\section{EXPERIMENTAL}

The overall objective of this test program is to evaluate the capabilities of activated carbon injection at four plants with configurations that together represent $78 \%$ of the existing coalfired generation plants. Following the technical approach summarized in this section, ADA-ES and the project team will evaluate activated carbon and other viable sorbents on a variety of coals and plant configurations, and perform long-term testing at the optimum condition for up to six weeks. The technical approach is outlined in a series of four technical tasks.

\section{Task 1. Design and Fabrication of Sorbent Injection System}

ADA-ES, the primary test contractor, will provide the majority of the process equipment that will travel from site to site. This equipment will be sized and designed to cover the expected range of plant sizes (70-500 MW) and flue gas conditions, and has the flexibility for both baghouse and ESP applications.

\section{Task 2. Site-Specific Activities Including Field-Testing}

This task has seven subtasks that will be repeated for the four host sites. A summary of these subtasks is presented in Table 3. The four sites identified for testing are Sunflower Electric's Holcomb Station, AmerenUE's Meramec Station, AEP's Conesville Station, and a fourth site to be finalized during the next reporting period. Testing during this quarter was conducted at Holcomb Generating Station and Meramec Station. Descriptions of Holcomb and Meramec are included below.

Table 3. Task 2 Subtasks (to be repeated at each test site).

\begin{tabular}{|l|l|}
\hline Subtask & Description \\
\hline 2.1 & Host site kickoff meeting, Test Plan, and QA/QC plan \\
\hline 2.2 & Design and install site-specific equipment \\
\hline 2.3 & Field-tests \\
2.3 .1 & Sorbent selection \\
2.3 .2 & Sample and data coordination \\
2.3 .3 & Baseline tests \\
2.3 .4 & Parametric tests \\
2.3 .5 & Long-term tests \\
\hline 2.4 & Data analysis \\
\hline 2.5 & Sample evaluation \\
\hline 2.6 & Economic analysis \\
\hline 2.7 & Site report \\
\hline
\end{tabular}




\section{Sunflower Electric's Holcomb Station, Unit 1}

Holcomb Station is located near Garden City, Kansas. The unit is a load-following subcritical 360-MW pulverized coal opposed-fired Babcock \& Wilcox Carolina-type radiant boiler designed to burn PRB coal. The existing unit is equipped with three spray dry absorber (SDA) modules followed by two very low air-to-cloth ratio reverse air fabric filters. A sketch of the Unit 1 gas path with mercury measurement locations identified is shown in Figure 1. Holcomb typically burns $100 \%$ PRB coal. Holcomb will burn up to about five different coals during the test program, but Jacobs Ranch (located near Gillette, Wyoming) and Black Thunder (Black Thunder mine near Wright, Wyoming) were fired during the coal blending, baseline, and parametric tests. Key operating parameters for Holcomb Unit 1 are shown in Table 1.

Figure 1. Sketch of Holcomb Unit 1 Spray Dryer Absorber and Fabric Filter Modules.

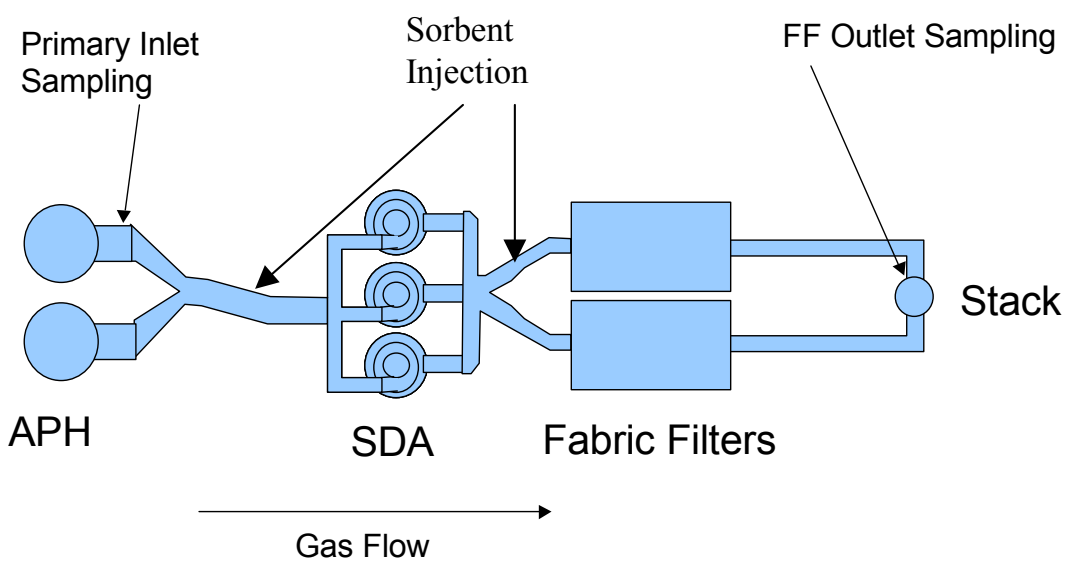




\section{AmerenUE's Meramec Unit 2}

Meramec Station is located in St. Louis County, Missouri. The test unit (Unit 2) is a loadfollowing sub-critical 140-MW (gross) pulverized coal, tangentially fired, electric generating unit that burns $100 \%$ PRB coal. The unit uses a two-section vertical, tubular air preheater. The unit is equipped with an ESP for particulate removal. During the 2004 spring outage, Unit 2 was retrofitted with low- $\mathrm{NO}_{\mathrm{x}}$ burners and separated overfire air for control of $\mathrm{NO}_{\mathrm{x}}$ emissions.

The ESP on Unit 2, designed by American Air Filter Company, Inc., is comprised of five electrical fields and three mechanical fields.

For sorbent injection testing with injection upstream of the ESP, only one-half of the 140MW flue gas stream is being treated. A sketch showing one-half of the Unit 2 flue gas path is shown in Figure 2 and a photograph is shown in Figure 3. Tests will be conducted to determine the mercury removal efficiency when injecting sorbent across the ESP. Data will also be available to determine the amount of mercury captured in-flight prior to entering the ESP. Key operating parameters for Meramec Unit 2 are shown in Table 1.

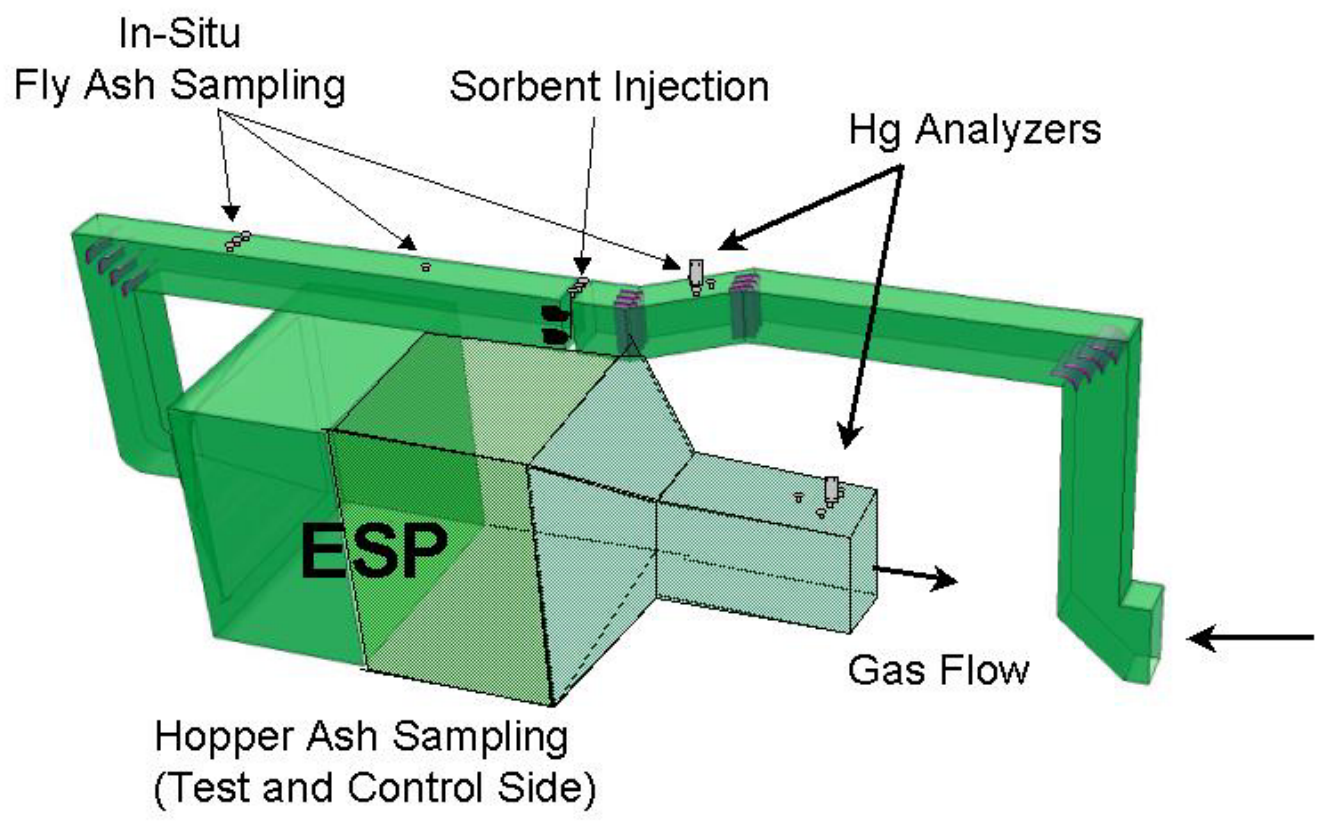

Figure 2. Sketch of East Half of Meramec Unit 2 Testing Layout. 


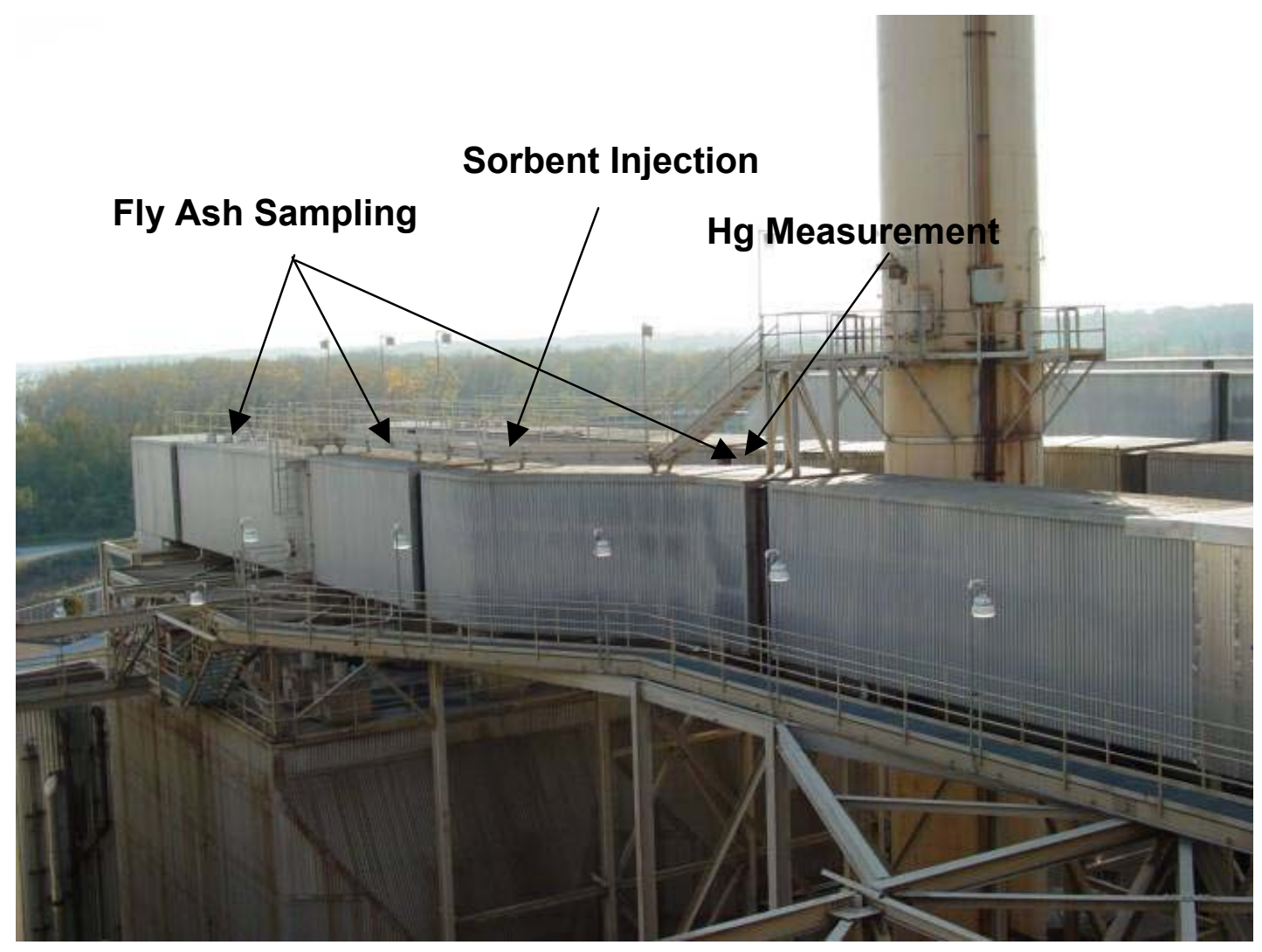

Figure 3. Photo of East ESP Inlet Duct, Meramec Unit 2.

\section{Subtask 2.1. Host Site Planning and Coordination}

Efforts within this subtask include planning the site-specific tests with the host site utility, DOE/NETL, and contributing team members. The planning process includes meeting with plant personnel, corporate, and environmental personnel to discuss and agree upon the overall scope of the program, the potential impact on plant equipment and operation, and to gather preliminary information necessary to develop a detailed draft Test Plan and scope of work. Efforts include identifying any permit requirements, developing a quality assurance/quality control plan, finalizing the site-specific scope for each of the team members, and putting subcontracts in place for manual flue gas measurements, including Ontario Hydro mercury measurement services.

\section{AEP, Conesville}

Field-testing is scheduled for spring 2005 at Conesville. Specific activities during this reporting period are listed below.

- A Host Site Agreement has been sent to AEP for review. It is expected the agreement will be finalized during the next reporting period.

- ADA-ES personnel are working with Conesville personnel to identify site-specific requirements. A plant procurement document will be developed and submitted to the plant during the site kickoff meeting (tentatively scheduled for December 2005). 


\section{Subtask 2.2. Design, Fabricate, and Install Equipment}

During this subtask, equipment will be identified, designed, fabricated when necessary, and installed at the host site. Some components are site-specific such as the sorbent distribution manifold and sorbent injectors (if possible, these components will be reused at multiple sites). This equipment must be sized, designed, and fabricated for the specific plant arrangements and ductwork configurations. Required site support includes installation of the injection and sampling ports (if not available), installation of required platforms and scaffolding, compressed air, electrical power, wiring plant signals including boiler load to the injection skid and control trailer, and the balance of plant engineering. The host utility will be responsible for all permitting and any variance requirements.

The sorbent injection system was installed at Meramec in August 2004. The system, pictured in Figure 4, has a 2,500- $\mathrm{ft}^{3}$ storage capacity, which is capable of holding approximately $40,000 \mathrm{lbs}$ of sorbent material. The system is also equipped with dual feeder/blower assemblies capable of accurately delivering $0-1,000 \mathrm{lbs} / \mathrm{hr}$ to the desired injection location. Other features include variable speed blowers, silo load cells, increased efficiency vent filter, and Ethernet connectivity for remote monitoring. A photo of the monitoring screen is shown in Figure 5.

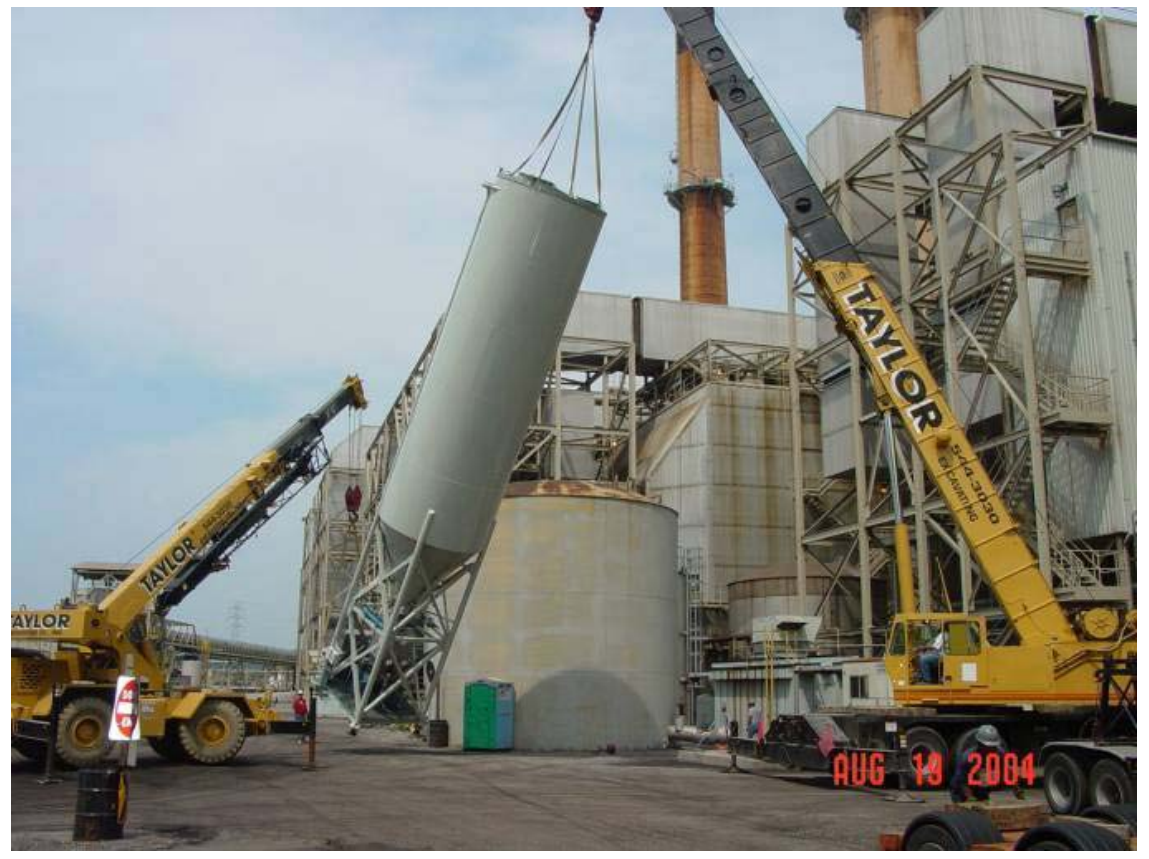

Figure 4. Photo of Injection Silo Installation at Meramec. 


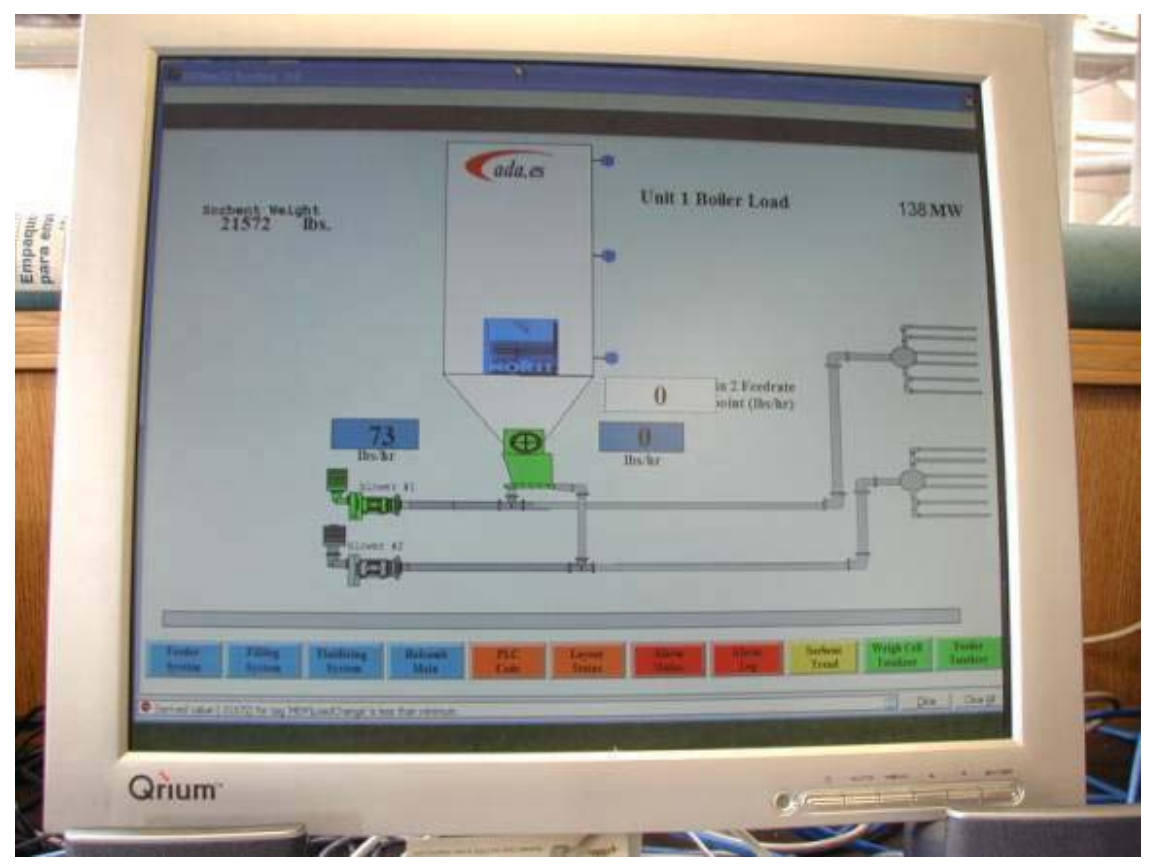

Figure 5. Photo of Injection Silo Control User Interface at Meramec.

\section{Subtask 2.3. Field-Testing}

The field-tests will be accomplished through a series of five (5) steps. A summary of these steps is presented below.

\subsubsection{Sorbent Selection}

To assist in the sorbent selection process, a sorbent screening device (SSD) designed by ADA-ES was used to compare the performance of candidate sorbents. This portable device can be taken to any power plant and used to extract and test an actual flue gas sample from anywhere in the process. It was designed to simulate the gas velocity, temperature, sorbent loading, and ash loading of a full-scale fabric filter. Because the device simulates a section of a full-scale fabric filter, results can be directly scaled to full-scale injection applications. A modified version of this system was also successfully used at Meramec to predict the performance of sorbents injected into an ESP. A description of the device was included in the last quarterly report.

\subsubsection{Sample and Data Coordination}

ADA-ES engineers coordinated with plant personnel to retrieve the necessary plant operating data files and determine appropriate samples to collect during baseline, parametric, and longterm testing periods. Samples were collected based upon a Sample and Data Management Plan developed for the site. An example of the sampling schedule for Meramec is shown in Table 4. A hopper diagram for Meramec is shown in Figure 6 for reference. Additional descriptions of the sample management protocol are included in the previous quarterly report. 
Table 4. Example of Sample Collection Schedule.

\begin{tabular}{|c|c|c|c|}
\hline $\begin{array}{c}\text { Test } \\
\text { Condition }\end{array}$ & Type & Frequency & Comments \\
\hline \multirow{3}{*}{ Baseline } & Coal & Daily & 1 liter \\
\hline & ESP Ash & $\begin{array}{l}\text { Daily: } \\
\text { 2C } 3,2 \mathrm{C} 7,2 \mathrm{C} 11 \\
2 \text { samples per week: } \\
\text { All Hoppers on Test Side }\end{array}$ & $\begin{array}{l}1 \text { liter } \\
1 \text { liter }\end{array}$ \\
\hline & Bottom Ash* & 2 samples per week & 1 liter \\
\hline \multirow{3}{*}{ Parametric } & Coal & Daily & 1 liter \\
\hline & In-Flight Fly Ash & TBD & 1 liter \\
\hline & ESP Ash & $\begin{array}{l}\text { Daily: } \\
\quad 2 \mathrm{C} 3,2 \mathrm{C} 7,2 \mathrm{C} 11\end{array}$ & 1 liter \\
\hline \multirow{6}{*}{$\begin{array}{l}\text { Long- } \\
\text { Term }\end{array}$} & Coal & Daily & 1 liter \\
\hline & In-Flight Fly Ash & TBD & 1 liter \\
\hline & ESP Ash & $\begin{array}{l}\text { Daily: } \\
\text { 2C10,2C11 }\end{array}$ & 1 liter \\
\hline & & $\begin{array}{l}2 \text { samples per week: } \\
\text { All Hoppers on Test Side }\end{array}$ & 1 liter \\
\hline & & $\begin{array}{l}1 \text { sample per week: } \\
\text { Hoppers } 2 \mathrm{C}-2,2 \mathrm{C}-6,2 \mathrm{C}-10 \\
1 \text { sample per week: } \\
\text { Hoppers } 2 \mathrm{C}-11,2 \mathrm{C}-10\end{array}$ & $\begin{array}{l}1 \text { liter } \\
5 \text { gallon }\end{array}$ \\
\hline & Bottom Ash* & 2 samples per week & 1 liter \\
\hline
\end{tabular}




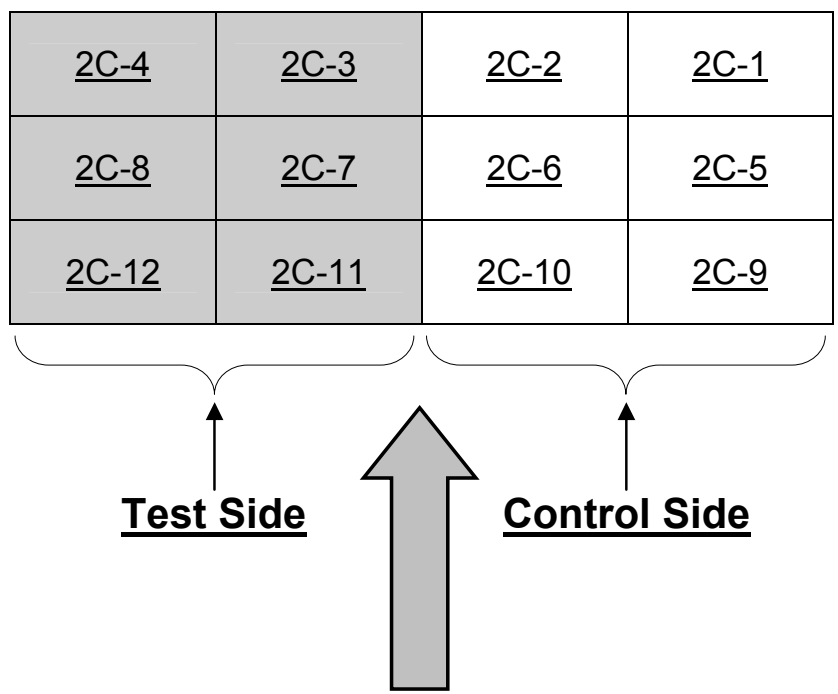

Gas Flow

Figure 6. ESP Hopper Layout at Meramec.

\subsubsection{Baseline Testing}

During the one-week baseline testing period at Meramec, 100\% subbituminous coal was fired. Coal was delivered to the unit from the coal pile serving all four units at Meramec. Coal in the pile is from four different mines in the Powder River Basin. Ontario Hydro mercury measurements, EPA M26a, and EPA M29 measurements were conducted in conjunction with SCEM measurements during this step.

\subsubsection{Parametric Testing}

A series of parametric tests was conducted to determine the optimum operating conditions for several levels of mercury control, especially those options to achieve mercury control levels above that which is possible with standard activated carbon. Parametric tests were conducted between August 30 and September 27, 2004. Primary variables of interest included:

- Sorbent type

- DARCO FGD (benchmark sorbent, no chemical treatment)

- FGD-E3 (halogen-treated)

- Sorbent injection concentration

- Enhancement additive with/without sorbent injection using coal additives

\section{Sorbent Type and Injection Concentration}

Two sorbents were evaluated during the parametric test period. The benchmark sorbent was DARCO FGD, a Texas lignite coal-based activated carbon product supplied by NORIT 
Americas. FGD-E3 was chosen as the second sorbent because of the promising performance at Holcomb and the competitive price. A brief description of the test sorbents is listed below:

- DARCO FGD: Activated carbon made from Texas lignite coal. General physical properties for DARCO FGD are:

- Surface area $=600 \mathrm{~m}^{2} / \mathrm{g}$

- Bulk density, tamped $=32 \mathrm{lb} / \mathrm{ft}^{3}$

- Particle size, mean $=17-20 \mu \mathrm{m}$

- FGD-E3: Texas lignite coal-based activated carbon treated with a halogen for improved performance in halogen-deficient gas streams. This sorbent is available on an experimental basis through NORIT Americas. Its physical characteristics are similar to DARCO FGD.

\subsubsection{Long-Term Testing}

A 30-day long-term test at Holcomb was completed in July and August during this reporting period. Long-term testing at Meramec will be conducted in October and November at the "optimum" settings as determined in the parametric tests and approved by both DOE and the host utility. It is the intent of DOE that these settings represent the maximum mercury removal achievable within the operating constraints of the plant. The goal of this step is to obtain sufficient operational data on removal efficiency over a 30-day period, the effects on the particulate control device, the effects on the sulfur control equipment, effects on byproducts, and impacts to the balance of plant equipment to prove viability of the process and determine the economics. During these tests, Ontario Hydro measurements are conducted at the inlet and outlet of the pollution control device(s) at least once.

\section{Subtask 2.4. Data Analysis}

Data collection and analysis for this program are designed to measure the effect of sorbent injection on mercury control and the impact on the existing pollution control equipment. The mercury levels and plant operation will be characterized without sorbent injection, during coal blending or coal additive testing, and with various injection rates and possible combustion modifications as defined by the final Site Test Plan.

\section{Subtask 2.5. Coal and Byproduct Evaluation}

Coal and combustion byproduct samples collected throughout the field-test will be analyzed in this task. During all test phases, samples of coal, fly ash, and scrubber waste (when applicable) will be collected. Ultimate and proximate analyses will be performed and mercury, chlorine, and sulfur levels will be determined in the coal. Activated carbon injection will result in the fly ash and scrubber materials being mixed with a certain amount of the mercury-containing sorbent. The ash samples will be analyzed at a minimum for mercury and LOI. Scrubber feed limestone, solids product discharge, and blowdown will be analyzed for mercury. Because of the apparent influence of $\mathrm{HCl}$ on sorbent effectiveness, $\mathrm{HCl}$ measurements will be conducted and samples analyzed to determine if there is a correlation between sorbent effectiveness and $\mathrm{HCl}$ concentrations. 


\section{Subtask 2.6. Economic Analysis}

After completion of testing and analysis of the data at each plant, the requirements and costs for full-scale permanent commercial implementation of the selected mercury control technology will be determined. The ADA-ES/ALSTOM program team will meet with the host utility plant and engineering personnel to develop plant-specific design criteria. Process equipment will be sized and designed based on test results and the plant-specific requirements (reagent storage capacity, plant arrangement, retrofit issues, winterization, controls interface, etc.). A conceptual design document will be developed. Finally, a budget cost estimate will be developed to implement the control technology.

\section{Subtask 2.7. Site Report}

A site report will be prepared documenting measurements, test procedures, analyses, and results obtained in Task 2. This report is intended to be a stand-alone document providing a comprehensive review of the testing that will be submitted to the host utility.

\section{Task 3. Technology Transfer}

Technology transfer activities include participation in DOE/NETL-sponsored meetings, EPA Hg MACT Stakeholder meetings, presentations at conferences, and publication of technical papers. Abstracts were submitted to several upcoming conferences including the Mega Symposium and the Low-Rank Fuels Conference. Presentation of results from tests conducted at Holcomb is planned.

\section{Task 4. Program Management and Reporting}

The final task provides time for overall program management and time to complete DOE's reporting requirements. This task will also support periodic meetings with DOE to discuss progress and obtain overall direction of the program from the DOE project manager. In addition to the standard financial and technical reports, additional deliverables will include topical reports for each site tested. The Project Schedule and Milestones are presented in Table 5. 
Table 5. Project Schedule and Milestones.

\begin{tabular}{|c|c|c|}
\hline Activity & Target Date & Actual Date \\
\hline \multicolumn{3}{|l|}{ Holcomb } \\
\hline Site Kickoff Meeting & $12 / 16 / 03$ & $12 / 16 / 03$ \\
\hline Complete Sorbent Screening Tests & $3 / 4 / 04$ & $3 / 2 / 04$ \\
\hline Complete Equipment Installation & $5 / 21 / 04$ & $4 / 21 / 04$ \\
\hline Complete Baseline Testing & $5 / 21 / 04$ & $5 / 20 / 04$ \\
\hline Initiate Parametric Testing & $5 / 24 / 04$ & $5 / 22 / 04$ \\
\hline Complete Parametric Testing & $6 / 11 / 04$ & $6 / 11 / 04$ \\
\hline Initiate Long-Term Testing & $7 / 7 / 04$ & $7 / 7 / 04$ \\
\hline Complete Team Meeting and Site Tour & $7 / 21 / 04$ & $7 / 21 / 04$ \\
\hline Complete Long-Term Test & $8 / 6 / 04$ & $8 / 6 / 04$ \\
\hline Complete Economic Analysis & $5 / 31 / 05$ & \\
\hline Complete Byproduct Analysis Evaluations & $5 / 31 / 05$ & \\
\hline Complete Site Report & $6 / 30 / 05$ & \\
\hline \multicolumn{3}{|l|}{ Meramec } \\
\hline Site Kickoff Meeting & $4 / 20 / 04$ & $4 / 20 / 04$ \\
\hline Complete Pre-Baseline Testing & $6 / 25 / 04$ & $6 / 23 / 04$ \\
\hline Complete Sorbent Screening Tests & $10 / 18 / 04$ & \\
\hline Complete Equipment Installation & $9 / 5 / 04$ & $8 / 23 / 04$ \\
\hline Complete Baseline Testing & $9 / 5 / 04$ & $8 / 27 / 04$ \\
\hline Initiate Parametric Testing & $9 / 6 / 04$ & $8 / 30 / 04$ \\
\hline Complete Parametric Testing & $10 / 17 / 04$ & $9 / 27 / 04$ \\
\hline Complete Team Meeting and Site Tour & $12 / 17 / 04$ & \\
\hline Initiate Long-Term Testing & $10 / 18 / 04$ & \\
\hline Complete Long-Term Test & $12 / 17 / 04$ & \\
\hline Complete Economic Analysis & $8 / 31 / 05$ & \\
\hline Complete Byproduct Analysis Evaluations & $8 / 31 / 05$ & \\
\hline Complete Site Report & $9 / 30 / 05$ & \\
\hline \multicolumn{3}{|l|}{ Conesville } \\
\hline Site Kickoff Meeting & $4 \mathrm{Q} 04$ & \\
\hline Initiate Field-Testing & 2Q05 & \\
\hline Complete Field-Testing & 3Q05 & \\
\hline \multicolumn{3}{|l|}{ Site 4} \\
\hline Site Kickoff Meeting & $2 \mathrm{Q} 04$ & \\
\hline Initiate Field-Testing & $3 \mathrm{Q} 05$ & \\
\hline Complete Field-Testing & 4Q05 & \\
\hline
\end{tabular}


There are more than 90 individual team members from 21 organizations participating in this program. Current project co-funders include:

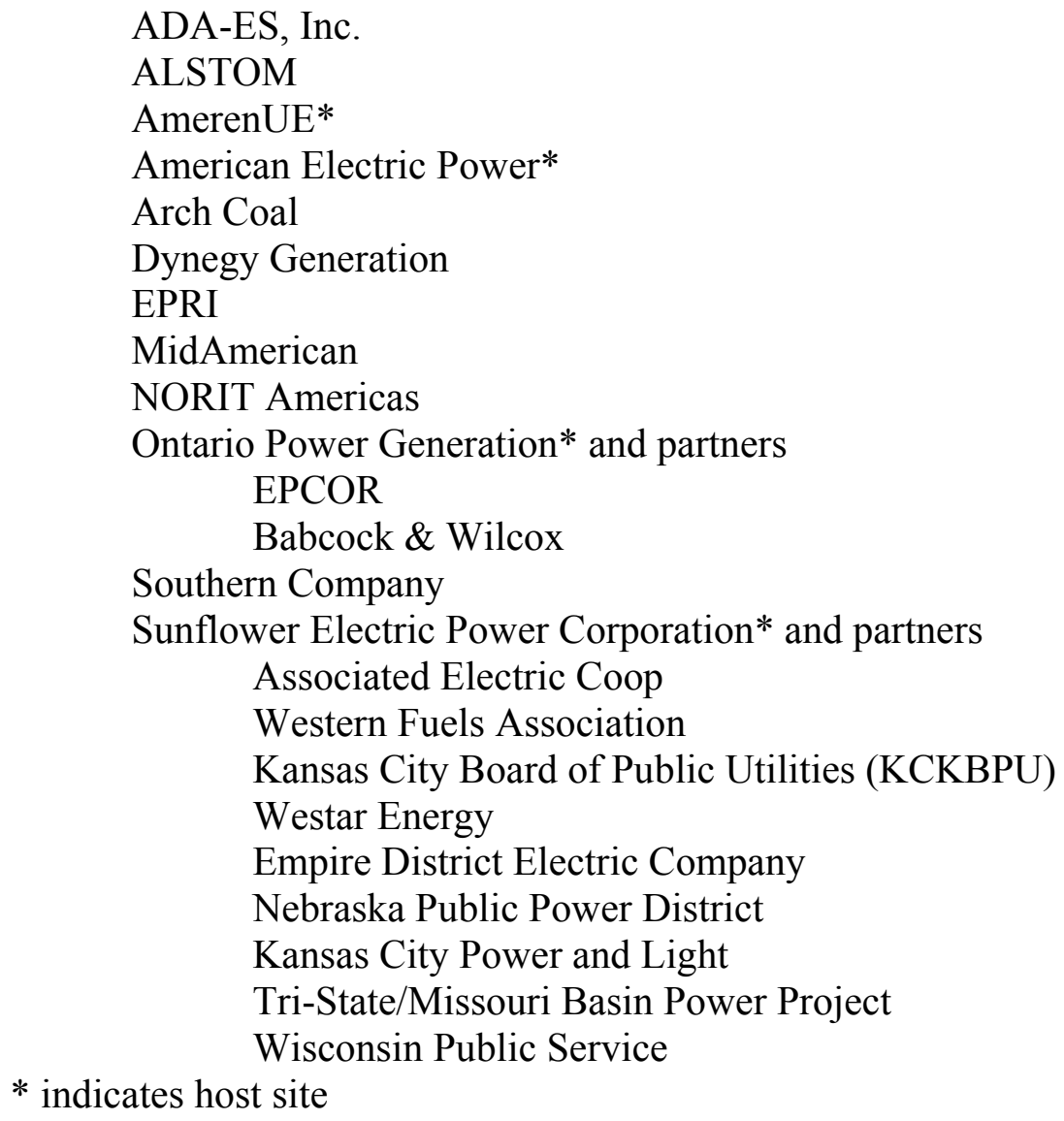

To facilitate information sharing, a project Web site is maintained for the project. The project Web site is password protected and available only to project participants.

Information available through the Web site includes all presentations, papers, reports, planning documents, schedules, and other information related to the project.

A schedule showing field-tests planned and completed at each test site is shown in Table 6 . 
Table 6. Field-Testing Schedule.

\begin{tabular}{|c|c|c|c|c|c|c|c|c|c|c|}
\hline & \multicolumn{4}{|l|}{2004} & \multicolumn{6}{|c|}{2005} \\
\hline Site & May & Jul & Sep & Nov & Jan & Mar & May & Jul & Sep & Nov \\
\hline Holcomb & & ] & & & & & & & & \\
\hline Meramec & & & 工 & $\square$ & & & & & & \\
\hline Conesville & & & & & & ᄃ & & 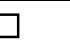 & & \\
\hline Site 4 & & & & & & & & ᄃ & & \\
\hline
\end{tabular}




\section{RESULTS AND DISCUSSION}

\section{Task 1. Design and Fabrication of Sorbent Injection System}

Design and fabrication of the sorbent injection system was completed during the second reporting period — January through March 2004.

\section{Task 2. Site-Specific Activities Including Field-Testing}

Long-term testing was completed at Holcomb Station during this reporting period. Baseline and parametric tests were completed at Meramec during this reporting period. Preliminary site-specific activities have begun at Conesville. Results from long-term testing at Holcomb are included under this task heading. Results from Meramec are being reviewed and will be included in the next quarterly report. Key activities at other sites are also presented.

\section{Subtask 2.3. Field-Testing, Holcomb Station}

\subsubsection{Sorbent Selection}

This task was completed during the third reporting period - April through June 2004.

\subsubsection{Sample and Data Coordination}

This task was completed during this reporting period when the final samples were collected from Holcomb. Data analysis, coal and byproduct evaluation is ongoing.

\subsubsection{Baseline Testing}

This task was completed during the third reporting period - April through June 2004.

\subsubsection{Parametric Testing}

This task was completed during the third reporting period - April through June 2004.

\subsubsection{Long-Term Testing}

Based upon results from parametric testing, FGD-E3 was chosen for 30 days of continuous injection at Holcomb from July 7 through August 6, 2004. For the first six days of testing, the injection concentration was adjusted to achieve $90 \%$ mercury removal. From Day 6 through 30, the injection concentration was set for nominally $1.2 \mathrm{lb} /$ MMacf. The logic on the injection skid was set to adjust the sorbent feederate with boiler load. The average removal for the 30-day test was $91 \%$, with an average removal of $93 \%$ for Days 6 through 30 . The average outlet concentration for Days 6 through 30 was $1.13 \mu \mathrm{g} / \mathrm{Nm}^{3}(0.83 \mathrm{lb} / \mathrm{TBTU}$, standard deviation $=0.30 \mathrm{lb} / \mathrm{TBTU}$ ). Trend graphs of the inlet and outlet mercury concentrations, mercury removal, and injection concentration for the 30-day test are presented in Figure 7. 

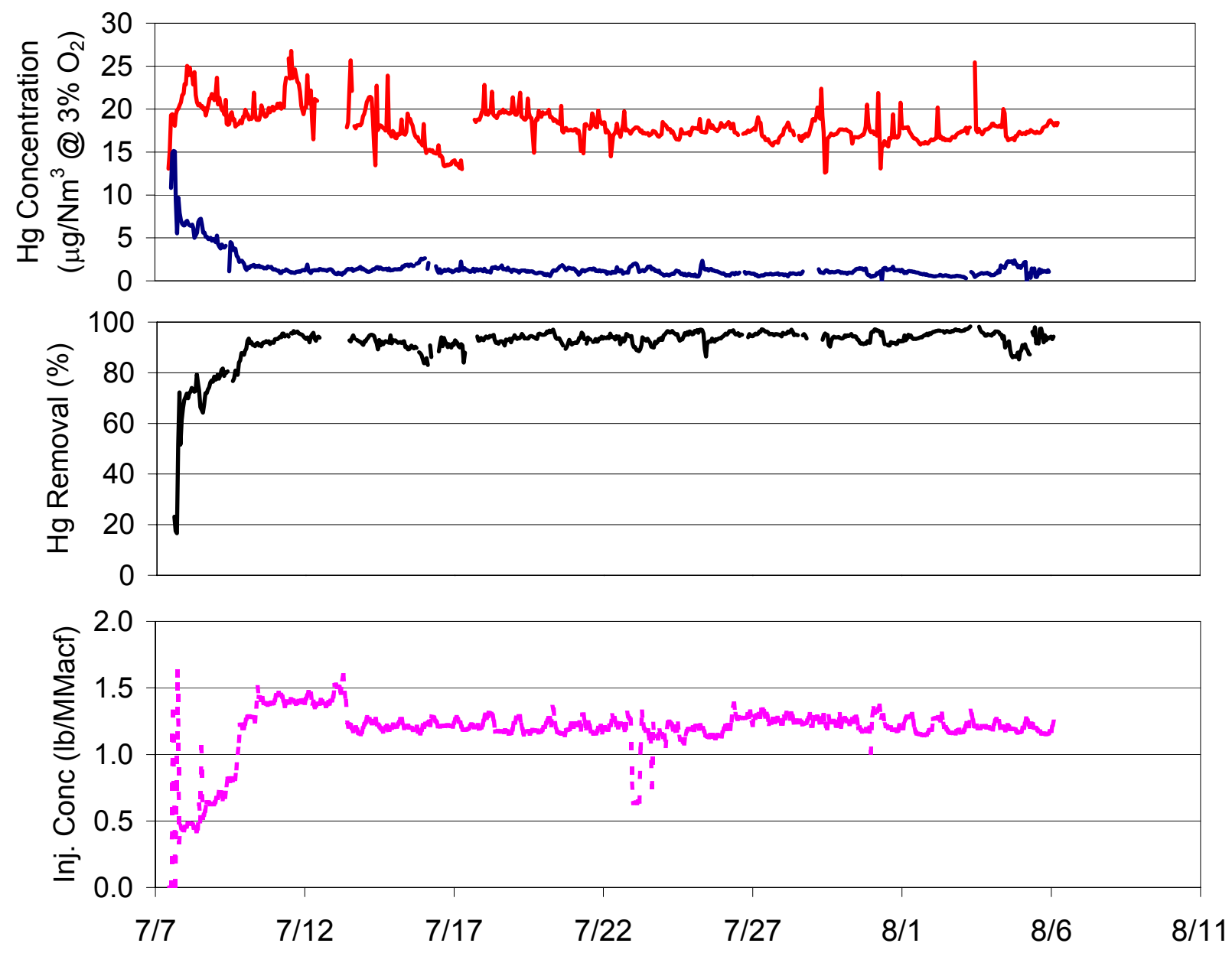

Figure 7. Mercury Removal During 30-Day Continuous Injection of FGD-E3.

\section{Subtask 2.4. Data Analysis}

Data collected during the baseline, parametric, and long-term test periods are currently being reviewed.

\section{Subtask 2.5. Coal and Byproduct Evaluation}

A total of 552 solid and liquid samples were collected from Holcomb during the field-testing campaign. Most of the ash samples, several coal samples, and at least one of all other sample types have been analyzed for mercury. Additional analyses, including coal ultimate and proximate analyses, and coal and ash chlorine analyses have been conducted. These data are being reviewed and will be summarized in the topical report for the site. 


\section{CONCLUSIONS}

Field-testing has been completed at Holcomb and initial tests have begun at Meramec. Results from Holcomb tests were reported in this and the previous quarterly reports.

The field program at Holcomb was very successful in that three different technologies were found that have the potential to produce high levels $(>80 \%)$ of mercury removal in this difficult application. These technologies are:

1. Coal Blending: By blending western bituminous coal with PRB coal, the mercury removal across the system increased to almost $80 \%$ even without injecting another sorbent. It is highly likely that firing a blend of Black Thunder and West Elk coals with ACI could result in greater than $90 \%$ mercury removal. Results with other coal blends must be evaluated.

2. Chemical Addition to the Coal: KNX, a proprietary chemical developed by ALSTOM Power, was found to enhance the performance of a standard activated carbon. Mercury removal of $86 \%$ was measured at a carbon feed rate of just 1.0 lb/MMacf.

3. Chemically Enhanced Sorbent: A proprietary product of NORIT Americas, FGD-E3, produced mercury removal in excess of $90 \%$ at an injection concentration of 1.2 lb/MMacf during a 30-day test.

The first two approaches were tested for very short periods and the results are discussed in the previous quarterly report. Additional longer-term tests need to be conducted to fully realize the capabilities of each approach.

Field-testing of chemical addition to the coal and enhanced sorbents for mercury control are being conducted at Meramec. Results are currently being reviewed and will be included in the next quarterly report. 


\section{LIST OF ACRONYMS AND ABBREVIATIONS}

$\begin{array}{ll}\text { ACI } & \text { Activated carbon injection } \\ \text { APC } & \text { Air pollution control } \\ \text { B\&W } & \text { Babcock \& Wilcox } \\ \text { COC } & \text { Chain of Custody } \\ \text { DOE } & \text { Department of Energy } \\ \text { ESP } & \text { Electrostatic precipitator } \\ \text { FGD } & \text { Flue gas desulfurization } \\ \text { ID Fan } & \text { Induced draft fan } \\ \text { kacfm } & \text { Thousand actual cubic feet per minute } \\ \text { kW } & \text { Kilowatt } \\ \text { MW } & \text { Megawatt } \\ \text { NETL } & \text { National Energy Technology Laboratory } \\ \text { O\&M } & \text { Operating and Maintenance } \\ \text { PAC } & \text { Powdered Activated Carbon } \\ \text { PC } & \text { Pulverized coal } \\ \text { PRB } & \text { Powder River Basin } \\ \text { SCA } & \text { Specific collection area } \\ \text { SCEM } & \text { Semi-continuous emission monitor } \\ \text { SDA } & \text { Spray dryer absorber } \\ \text { SGLP } & \text { Synthetic groundwater leaching procedure } \\ \text { SSD } & \text { Sorbent Screening Device } \\ \text { TCLP } & \text { Toxicity characteristic leaching procedure } \\ \end{array}$

